\title{
Implementasi Model Pembelajaran ATI (aptitude treatment interaction) Untuk Meninggkatkan Hasil Belajar dan Aktivitas Belajar Siswa Materi Geometri Ruang Kelas XII.IPA.1 SMA Negeri 4 Kota Bima Tahun Pelajaran 2019/2020
}

\author{
Ika Wirahmad ${ }^{1}$, Zainal Arifin ${ }^{2}$ \\ ${ }^{1}$ Sekolah Tinggi Keguruan dan Ilmu Pendidikan STKIP Bima \\ ${ }^{2}$ Guru Matematika SMAN 04 Kota Bima Nusa Tenggara Barat \\ Email: wirahmad.71@gmail.com \\ Email : zainalarifin2701@gmail.com
}

\begin{abstract}
ABSTRAK
Tujuan penelitian ini adalah mengetahui peningkatan aktivias dan hasil belajar matematika pada materi pokok Geometri Ruang siswa kelas XII.IPA.1 SMA Negeri 4 Kota Bima tahun pelajaran 2019/2020. Penelitian ini merupakan penelitian tindakan kelas (class room action research) yang direncanakan dilakukan dengan beberapa siklus, yang tahapannya terdiri dari perencanaan, pelaksanaan tindakan, observasi/evaluasi dan refleksi . Subjek penelitian ini adalah siswa kelas XII.IPA.1 SMA Negeri 4 Kota Bima dengan jumlah siswa 29 orang yang terdiri dari 16 orang siswi dan 13 orang siswa.

Tehnik pengumpulan data dengan menggunakan lembar observasi, dimana hasil aktifitas siswa minimal berkategori aktif dan aktifitas Guru minimal berkategori baik dan tes hasil belajar, tiap individu minimal $\geq 70$ dengan ketuntasan klasikal minimal $85 \%$ untuk mengetahui peningkatan yang terjadi.

. Berdasarkan hasil penelitian, diperoleh nilai rata-rata siswa pada siklus I sebesar 71,27 dengan ketuntasan klasikal $65,51 \%$. Karena pada siklus I belum memenuhi ketuntasan belajar klasikal yaitu $85 \%$ dari siswa yang mendapat nilai $\geq 70$, maka penelitian dilanjutkan ke siklus II. Pada siklus II, nilai rata-rata siswa 80,65 dengan ketuntasan klasikal 89,65\% yang artinya ketuntasan belajar klasikal sudah tercapai dan hasil belajar mengalami peningkatan. Sehingga dapat disimpulkan dengan peneranpan model pembelajaran ATI (Aptitude Treatment Interaction) dapat meningkatkan aktvitas dan hasil belajar siswa kelas XII.IPA.1 SMA Negeri 4 Kota Bima tahun pelajaran 2019/2020.
\end{abstract}

Kata kunci : Medel pembelajaran ATI (Aptitude Treatment Interaction), aktivitas dan hasil belajar.

\section{ABSTRACT}

The purpose of this study was to find out the improvement in activities and learning outcomes of mathematics in the subject matter Geometry of class XII.IPA.1 students in SMA Negeri 4 Kota Bima in the academic year 2019/2020. This research is a class action research (class room action research) which is planned to be carried out with several cycles, the stages of which consist of planning, implementing actions, observing / evaluating and reflecting. The subjects of this study were students of class XII.IPA.1 SMA Negeri 4 Kota Bima with a total of 29 students consisting of 16 students and 13 students.

Data collection techniques using observation sheets, where the results of student activities are at least active and the teacher's activities are at least categorized as good and tests of learning outcomes, each individual is at least $\geq 70$ with a classical completeness of at least $85 \%$ to find out the improvement.

Based on the results of the study, obtained an average value of students in the first cycle of 71.27 with a classical completeness of $65.51 \%$. Because in the first cycle did not meet the classical learning completeness that is $85 \%$ of students who scored nilai 70 , then the study continued to cycle II. In the second cycle, the average value of students is 80.65 with $89.65 \%$ classical completeness which means that classical learning completeness has been achieved and learning outcomes have increased. So it can be concluded with the implementation of the ATI learning model (Aptitude Treatment Interaction) can improve the activity and learning outcomes of students in class XII.IPA.1 SMA Negeri 4 Kota Bima in the academic year 2019/2020.

Keywords: ATI (Aptitude Treatment Interaction) learning model, learning activities and results. 


\section{PENDAHULUAN}

Dalam proses pembelajaran yang dilaksanakan, diharapkan mencapai sasaran sesuai dengan tujuan. Karena guru, siswa dan lingkungan belajar dapat mendukung dan menunjang keberhasilan pengajaran di sekolah.Belajar bukan masalah sekolah saja, tetapi masalah setiap manusia yang ingin maju dan berhasil. Belajar dapat dirumuskan sebagai suatu kegiatan bagi setiap orang yang dapat menghasilkan perubahan pengetahuan, ketrampilan, kebiasaan, kegemaran dan sikap. Sedangkan mengajar adalah suatu kegiatan dimana pengajar memberi fasilitas sedemikian hingga peserta didik dapat belajar.

Pembelajaran matematika yang menurut kenyataan sejarah merupakan penentu jatuh bangunya suatu negara dewasa ini. Sering dalam kenyataan di lapangan merupakan pelajaran yang dibenci dan ditakuti oleh siswa. Karena cara mengajar seorang guru matematika cenderung serius dan tidak ada hiburan sama sekali. Efek paling buruk akhirnya adalah minat siswa terhadap matematika semakin menurun dan prestasi dalam bidang matematika semakin buruk (Suherman dalam Marsiti,2005: 5).

Banyak peserta didik menngalami kesulitan dalam mempelajari dan menguasai konsepkonsep berhitung atau menyelesaikan soal. Peserta didik juga cenderung malas dan memiliki motivasi yang rendah untuk belajar matematika baik secara klasikal dikelas maupun belajar mandiri di rumah. Para guru sering kali mengalami beberapa kendala dalam upaya mencapai tujuan pembelajarann matematika. Hal ini terkait dengan kelemahan peserta didik antara lain: (1) Masih sedikit pengetahuann materi prasyarat yang baik, (2) Belum maksimalnya kemampuan untuk memahami serta mengenali konsep-konsep dasar matematika (aksioma, definisi, kaidah, atau teorema), (3) Kemampuan dan ketelitian dalam menyimak atau mengenali suatu persoalan masih kurang, (4) Kurangnya motivasi dalam kemampuan menyimak kembali sebuah jawaban yang diperoleh.

Menurut beberapa pakar pendidikan model pembelajaran dikembangkan dewasa ini kelihatan masih belum peduli dan bahkan belum mampu mengapresiasi serta mengakomodasi perbedaan-perbedaan individual siswa, berarti di dalam melaksanakan proses belajar mengajar guru memberikan layanan pembelajaran yang sama untuk semua siswa, baik yang memiliki kemampuan tinggi, sedang ataupun rendah. Dengan perlakuan demikian, siswa yang berbeda kecepatan belajarnya belum mendapatkan layanan pembelajaran yang sesuai dengan kemampuan masing-masing. Siswa yang lambat tetap saja tertinggal dari kelompok sedang. Sementara siswa yang cepat belum mendapatkan layanan yang optimal dalam pembelajaran. Proses pembelajaran yang berlangsung di kelas cenderung belum bisa mendorong mereka maju dan berkembang sesuai dengan kemampuan masing-masing. Salah 
satu prinsip atau asas mengajar menekankan pentingya "Individualitas", yaitu menyesuaikan pembelajaran dengan perbedaan individual siswa.

Model pembelajaran Aptitude - Treatment Interaction (ATI) dapat dijadikan sebagai salah satu alternatife untuk memperbaiki kualitas pembelajaran. Aptitude Treatment Interaction (ATI) adalah sebuah pendekatan atau model pembelajaran yang berusaha mencari dan menemukan perlakuan-perlakuan (treatment) yang cocok dengan perbedaan kemampuan (aptitude) siswa, yaitu perlakuan yang secara optimal efektif diterapkan untuk siswa yang berbeda tingkat kemampuannya ( Cronbach dalam Nurdin, $2005: 37$ ).

Dalam penelitian ini materi yang di berikan adalah Geometri Ruang. Untuk itu dalam pembelajaran ini siswa sering dilatih dengan soal- soal sesuai dengan bentuk perlakuan siswa. Tipe soal yang diberikan sama tetapi penyampaianya yang berbeda sesuai treatment masingmasing kemampuan siswa. Untuk siswa yang berkemampuan tinggi soal-soal Geometri Ruang terangkum dalam satu modul, untuk siswa yang berkemampuan sedang soal-soalnya terangkum dalam lembar kerja siswa yang diberikan pada regular teaching sedangkan untuk siswa yang berkemampuan rendah diberikan penjelasan secara bertahap dan dilakukan pengulangan berkali-kali untuk meningkatkan pemahaman siswa terhadap materi serta siswa dilatih dengan soal-soal Geometri Ruang yang terangkum dalam lembar kerja siswa.

Berdasarkan uraian diatas, peneliti tertarik untuk mengadakan penelitian dengan judul "Implementasi Model Pembelajaran ATI (Aptitude Treatment Interaction) Untuk Meninggkatkan Hasil Belajar dan Aktivitas Belajar materi Geometri Ruang Siswa kelas XII.IPA.1 SMAN 4 Kota Bima Tahun Pelajaran 2019/2020. “

\section{METODE PENELITIAN}

Adapun jenis penelitian yang digunakan adalah penelitian tindakan kelas (PTK). Penelitian tindakan kelas adalah studi sistem terhadap praktek pembelajaran di kelas dengan tujuan untuk memperbaiki dan meningkatkan kualitas proses pembelajaran dan hasil belajar siswa dengan melakukan tindakan tertentu (Depdiknas, 2004). Penelitian tindakan kelas ini menekankan pada suatu kajian yang benar-benar dari situasi alamiah kelas. Oleh karena itu pendekatan yang digunakan dalam penelitian ini adalah pendekatan kualitatif. Jenis penelitian ini adalah penelitian Kualitatif dan Kuantitatif yang dilaksanakan di SMAN 4 Kota Bima dengan alamat Kelurahan Rita Kecamatan Raba Kota Bima, penelitian dilakukann pada semester ganjil Tahun pelajaran 2019/2020. Sebagai subjek Penelitiannya adalah siswa kelas XII.MAN 4 Kota Tahun Pelajaran 2019/2020 dan Objek Penelitiannya Objek penelitian ini 
adalah implemementasi ATI dalam meningkatkan hasil belajar dan aktifitas siswa materi Geometri Ruang kelas XII.IPA.1 SMAN 4 Kota Bima tahun pelajaran 2019/2020.

Dalam penelitian ini peneliti terlibat secara langsung mulai dari awal sampai akhir penelitian dan berusaha menentukan pemecahan masalah yang ada berdasarkan data yang diperoleh dengan tahapan sebagai berikut : Siklus I a) Perencanaan Tindakan, b) Pelaksanaan Tindakan c) Observasi/Evaluasi dan d) Refleksi. Tahap siklus seterusnya akan dilaksanakan apabila siklus sebelumnya belum memenuhi keriteria ketuntasan yang di tetapkan.

Prosedur pada tiap siklus pada dasarnya sama, hanya saja pada siklus selanjutnya dilakukan perbaikan terhadap kekurangan dari segi perencanaan maupun pelaksanaan tindakan, yang diketahui dari hasil tes belajar siswa yang telah dianalisis. Untuk lebih jelasnya mengenai penelitian tindakan kelas dapat digambarkan sebagai berikut:

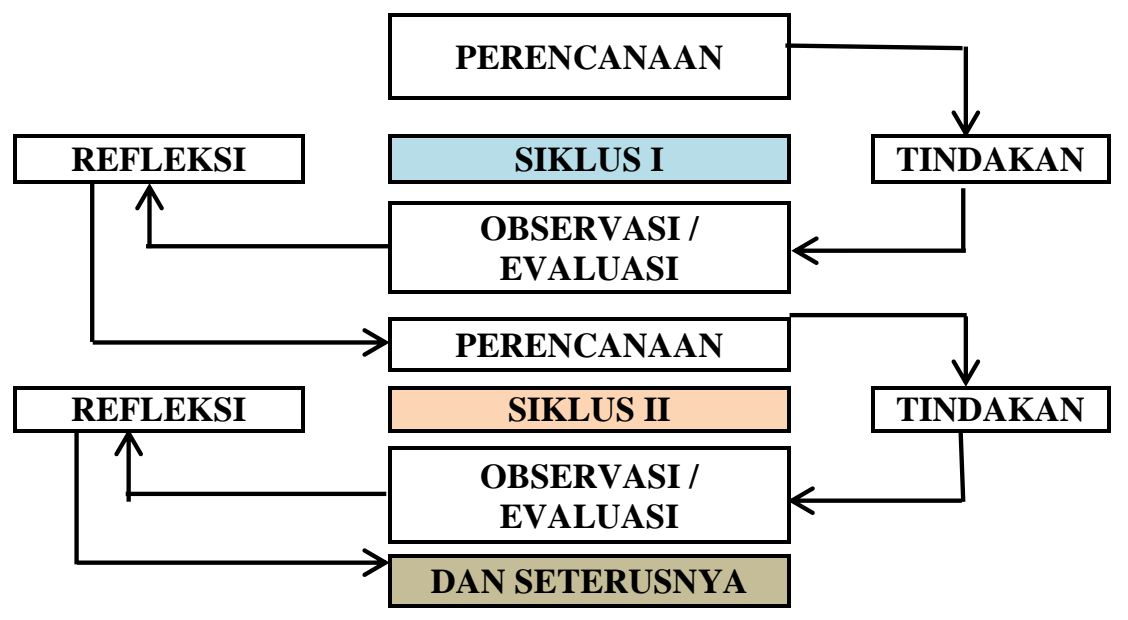

Gambar 1 : Skema Model Penelitian Tindakan Kelas Suharsimi Arikunto (Paizaluddin \& Ermalinda, 2014 : 34)

Adapun instrument penelitian yang digunakan adalah Lembar Observasi dan Tes hasil belajar yang menggunakan soal esay tiap siklus 5 soal, Untuk lembar observasi digunakan untuk mengetahui aktifitas siswa dan guru. Pengamatan dilakukan oleh observer (Teman sejawat) dan guru mata pelajaran sampai akhir pembelajaran. Pengamatan siswa dilakukan pada masing - masing yang berkemampuan tinggi, sedang, dan rendah. Pengamat menulis nomer - nomer kategori yang dominan muncul pada lembar pengamatan. Tes dalam hal ini dimaksudkan untuk mengetahui ketuntasan belajar siswa tiap siklus dengan menggunakan model ATI pada materi Geometri Ruang. Tes ini berupa soal-soal uraian (Essay) berkaitan dengan materi yang telah dipelajari dengan jumlah soal yang disajikan sebanyak 5 soal.

Setelah data terkumpul, perlu dilakukan analisis data agar data dapat dibaca dan diinterpretasikan serta mempunyai makna. Data-data yang dianalisis adalah : 
1. Data Observasi

a. Data hasil observasi aktivitas siswa

Data aktivitas siswa dalam proses pembelajaran diperoleh melalui pengamatan langsung dalam setiap pertemuan kelas yang diamati oleh observer dan mengacu pada lembar observasi aktivitas belajar siswa yang telah dibuat oleh peneliti. Setiap indikator aktivitas siswa dalam penelitian ini, penilaiannya berdasarkan aturan sebangai berikut:

a) Skor 4 diberikan jika semua deskriptor nampak

b) Skor 3 diberikan jika 2 deskriptor nampak

c) Skor 2 diberikan jika 1 deskriptor nampak

d) Skor 1 diberikan jika tidak ada deskriptor nampak

Rumus Menghitung skor aktivitas siswa :

$A s=\sum_{N} X$

Ket $:$ As $=$ Skor rata-rata aktivitas belajar siswa

$\sum x=$ Jumlah skor rata aktivitas belajar siswa

$\mathrm{N}=$ Jumalah Indikator

(dalam penelitian wulan agustina, 2014)

Untuk menghitung skor aktivitas belajar siswa digunakan rumus Ml (Mean ideal) dan SDI ( Standar Deviasi Ideal) yaitu:

$$
\begin{aligned}
& \mathrm{MI}=\frac{1}{2}(\text { Skor Tertinggi }+ \text { Skor Terendah }) \\
& \mathrm{SDI}=\frac{1}{3} \times M I
\end{aligned}
$$

Ket $:$ MI $=$ Mean ideal dan SDI $=$ standar deviasi ideal

Untuk menentukan keaktifan siswa dapat dilihat pada tabel berikut:

Tabel 1. kreteria untuk menentukan aktivitas belajar siswa

\begin{tabular}{|c|c|l|}
\hline \multicolumn{1}{|c|}{ Interval } & Nilai & Kategori \\
\hline As $\geq M I+1,5$ SDI & As $\geq 3,75$ & Aktif sekali \\
\hline MI+0,5 SDI $\leq$ As $<$ MI+1,5 SDI & $2,92 \leq$ As $<3,75$ & Aktif \\
\hline $\mathrm{MI}-0,5 \mathrm{SDI} \leq$ As $<$ MI+0,5 SDI & $2,08 \leq$ As $<3,75$ & Cukup aktif \\
\hline $\mathrm{MI}-1,5 \mathrm{SDI} \leq \mathrm{As}<\mathrm{MI}-0,5$ SDI & $1,25 \leq \mathrm{As}<2,08$ & Kurang aktif \\
\hline As $<\mathrm{MI}-1,5$ SDI & $\mathrm{As}<1,25$ & Sangat kurang aktif \\
\hline
\end{tabular}

(dalam penelitian wulan agustin) Nurkencana, 1993

Keterangan : As = Skor Rata-Rata Aktivitas Siswa 
Berdasarkan skor yang ditentukan, yaitu: skor tertinggi $=4$ dan skor terendah $=1$, maka:

$$
\begin{aligned}
\mathrm{MI} & =\frac{1}{2}(\text { Skor tertinggi }+ \text { skor terendah }) \\
& =\frac{1}{2}(4+1)=2,5 \\
\mathrm{SDI} & =\frac{1}{3} \times M I=\frac{1}{3} \times 2,5=0,83
\end{aligned}
$$

Untuk data aktivitas siswa dikatakan berhasil apabila termaksud pada kreteria aktif dan aktif sekali.

b. Data Aktivitas Guru

Peningkatan aktivitas guru dapat diketahui melalui observasi tarhadap prilaku guru selama melakukan proses pembelajaran dengan lembar observasi guru. Untuk menentukan rata-rata aktivitas guru dianalisis guru pada penelitian ini mengikuti aturan sebagai berikut:

a. Skor 4 diberikan jika semua deskriptor nampak

b. Skor 3 diberikat jika 2 deskriptor nampak

c. Skor 2 diberikan jika 1 deskriptor nampak

d. Skor 1 diberikan jika tidak ada deskriptor nampak

Untuk menentukan skor aktivitas guru digunakan rumus :

$\mathrm{Ag}=\frac{\sum x}{i}$

Ket: $\mathrm{Ag}=$ Skor Rata-Rata Aktivitas Guru

$\sum x=$ jumlah skor aktivitas guru dari masing-masing indikator

$$
\mathrm{i} \text { = banyaknya indikator }
$$

Untuk menetukan MI dan SDI dengan cara sebagai berikut:

$\mathrm{MI}=\frac{1}{2}($ skor terting $i+$ skor terendah $)=\frac{1}{2}(4+1)=2,5$

$\mathrm{SDI}=\frac{1}{3} \times M I=\frac{1}{3} \times 2,5=0,83$

Untuk menentukan keaktifan guru dapat dilihat pada tabel berikut:

Tabel 2. kriteria untuk menentukan aktivitas guru

\begin{tabular}{|c|c|l|}
\hline \multicolumn{1}{|c|}{ Interval } & Nilai & \multicolumn{1}{c|}{ Kategori } \\
\hline \multicolumn{1}{|c|}{$\mathrm{Ag} \geq \mathrm{MI}+1,5 \mathrm{SDI}$} & $\mathrm{Ag} \geq 3,75$ & Aktif sekali \\
\hline $\mathrm{MI}+0,5 \mathrm{SDI} \leq \mathrm{Ag}<\mathrm{MI}+1,5 \mathrm{SDI}$ & $2,92 \leq \mathrm{Ag}<3,75$ & Aktif \\
\hline $\mathrm{MI}-0,5 \mathrm{SDI} \leq \mathrm{Ag}<\mathrm{MI}+0,5 \mathrm{SDI}$ & $2,08 \leq \mathrm{Ag}<2,92$ & Cukup aktif \\
\hline $\mathrm{MI}-1,5 \mathrm{SDI} \leq \mathrm{Ag}<\mathrm{MI}-0,5 \mathrm{SDI}$ & $1,25 \leq \mathrm{Ag}<2,08$ & Kurang aktif \\
\hline $\mathrm{Ag}<\mathrm{MI}-1,5 \mathrm{SDI}$ & $\mathrm{Ag}<1,25$ & Sangat kurang aktif \\
\hline
\end{tabular}


(dalam penelitian wulan agustina) Nurkencana 1993

Ket: $\mathrm{Ag}=$ skor rata-rata guru

Adapun target yang ingin dicapai dari aktivitas guru minimal tergolong

kategori baik

2. Data Hasil Tes

Untuk mengetahui hasil belajar siswa, hasil tes belajar dianalisis secara deskriptif, yaitu menentukan skor rata-rata hasil tes. Analisis untuk mengetahui hasil tes belajar, dengan menggunakan rumus sebagai berikut:

$\mathrm{M}=\frac{\sum_{i=1}^{n} X i}{n}$

Keterangan:

$\mathrm{M}=$ Mean (rata-rata) Tes hasil belajar siswa

$\mathrm{X}=$ Skor yang diperoleh masing-masing siswa

$\mathrm{n}=$ Banyaknya siswa yang mengikuti tes

Ketuntasan Individu

Setiap siswa dalam proses belajar mengajar dikatakan tuntas apabila memperoleh nilai $\geq 70$. Nilai ketuntasan minimal sebesar 70 dipilih karena sesuai dengan kemampuan individu, hal ini sesuai dengan standar ketuntasan belajar siswa pada di SMAN 4 Kota Bima.

Ketuntasan Klasikal :

$\mathrm{KK}=\frac{M}{N} \mathrm{X} 100 \%$

Dengan KK = Ketuntasan Klasikal

$\mathrm{M}=$ Banyak Siswa Yang Tuntas

$\mathrm{N}$ = banyak Siswa

Secara klasikal terdapat minimal $85 \%$ dari jumlah siswa dalam suatu kelas telah mencapai ketuntasan belajar.

Sebagai Indikator keberhasilan dalam penelitian ini adalah Aktivitas belajar disiswa dikatakan meningkat apabila minimal berkategori Aktif dan Aktifitas Guru di katakana meningkat apabila minimal berkategori Baik. Untuk tes hasil belajar dikatakan 
berhasil apabila hasil belajar siswa mencapai nilai KKM yang telah ditetapkan oleh sekolah yaitu $\geq 70$ dan ketuntasan klasikal mencapai $\geq 85 \%$.

\section{HASIL DAN PEMBAHASAN}

Berdasarkan analisis data tentang aktivitas siswa selama proses pembelajaran berlangsung pada siklus I diperoleh skor rata-rata untuk pertemuan 1 dan 2 yaitu 2,50 dan 2,67 berkategori cukup aktif. Sedangkan hasil evaluasi siklus I dari 29 siswa yang mengikuti tes memperoleh nilai rata-rata sebesar 71,27. Hal ini menunjukan bahwa indikator keberhasilan penelitian pada siklus I ini belum tercapai.

Hasil ini disebabkan karena pada siklus I pertemuan pertama pada penggunaan waktunya masih belum teratur pemanfaatan waktu yang tersedia, sehingga kegiatan pada akhir pembelajaran tidak terlaksanakan dalam membuat kesimpulan, sehingga skor nilai ratarata aktivitas siswa dalam belajar pada siklus I pertemuan 1 dan 2 berkategori cukup aktif dengan rata-rata 2,50 dan 2,67. Pada siklus I pertemuan kedua guru berusaha memperbaiki kekurangan-kekurangan pada pertemuan pertama, namun ada beberapa masalah dari aktivitas siswa pada pertemuan pertama yaitu PR yang diberikan guru hanya sebagian siswa saja yang mengerjakannya, siswa tidak banyak mengingat pelajaran yang diperoleh sebelumnya, sehingga sedikit menghambat kegiatan pembelajaran, ada siswa kurang memperhatikan penjelasan guru katika proses belajar siswa pada pertemuan kedua mencapai 2,67 berkategori cukup aktif. Sedangkan evaluasi pada siklus I, siswa yang dapat mengikuti tes adalah 29 siswa dan mandapatkan nilai rata-rata 71,27 dengan ketuntasan klasikal 65,51\%.

Pada siklus II pertemuan pertama, sebelum guru memulai pembelajaran, terlebih dahulu guru membahas soal yang dianggap sulit oleh siswa yang pada saat evaluasi siklus I. Kemudian guru menghibau siswa agar lebih aktif dalam belajar, diskusi dan tidak malu untuk bertanya, baik kepada guru dan siklus II pertemuan pertama guru berusaha meningkatkan pengelolaan kelas dengan baik, sehingga pada siklus II ini aktivitas siswa dalam belajar pada pertemuan 1 dan 2 berkategori aktif dengan rata-rata 3,17 dan 3,50 pada siklus II pertemuan dua siswa sudah terbiasa dengan model pembelajaran ATI sehingga pada kegiatan pembelajaran siswa tidak ragu-ragu untuk mempresentasikan hasil diskusinya. Sedangkan evaluasi pada siklus II siswa yang dapat mengikuti tes sebanyak 29 siswa, dan mendepatkan nilai rata-rata 83,55 dengan ketuntasan klasikal 89,65\%.

Berdasarkan analisis data tentang aktivits siswa selama proses pembelajaran yang berlangsung pada siklus II di peroleh skor rata-rata aktivitas siswa dalam belajar pada pertemuan I dan II dari 29 siswa yang mengikuti tes memperoleh nilai rata-rata sebesar 83,55 
dan secara ketuntasan klasikal telah tercapai $\geq 85 \%$. Hal ini disebabkan karena guru aktif melakukan perbaikan-perbaikan pada siklus II. Sehingga indikator keberhasilan penelitian yaitu diperoleh aktivitas siswa aktif.

Dari hasil penelitian yang diperoleh, ternyata penerapan model pembelajaran ATI dapat meningkatkan aktivitas belajar siswa kelas XII.IPA.1 pada materi pokok Geometri Ruang dan dapat meningkatkan hasil belajar.

\section{KESIMPULAN}

Berdasarkan hasil dari analisis dan pemahaman dari hasil penelitian, maka dapat disimpulkan bahwa Penerapan metode pembelajaran ATI (Aptitude Treatment interaction) dapat meningkatkan aktivitas dan hasil belajar siswa kelas XII.IPA.1 semester I SMA Negeri 4 Kota Bima pada materi pokok Geometri Ruang. Peningkatan ini dapat dilihat dari aktivitas siswa pada siklus 1 dengan skor rata-rata aktivitas siswa dalam belajar pada pertemuan I dan II adalah 2,57 dan 2,62 ( kategori cukup aktif) dilanjutkan ke siklus II dengan skor rata-rata aktivitas siswa dalam belajar pada pertemuan I dan II adalah 3,37 dan 3,50 (kategori aktif), sedangkan pada saat evaluasi ketuntasan klasikal kelas pada siklus I mencapai 65,51\% setelah dilanjutkan ke siklus II didapatkan ketuntasan klasikal kelas mencapai 89,65\%. Dengan demikin, metode pembelajaran ATI (Aptitude Treatment interaction) dapat dikatakan berhasil dan efektif digunakan pada proses belajar mengajar pada materi pokok Geometri Ruang.

\section{DAFTAR PUSTAKA}

Ismayani, I. (2011). Penerapan Model Pembelajaran Aptitude Interaction (ATI) dalam Upaya Meningkatkan Kemampuan Pemecahan Masalah Matematis dan Motivasi Belajar Siswa. Jurnal Penelitian Tindakan Kelas (PTK). Vol. 6.

Pertiwi, Wiwit Candra. (2017). Penerapan Model Pembelajaran Aptitude Treatment Interaction (ATI) Untuk Meningkatkan Hasil Belajar Peserta Didik Pada Pokok Bahasan Seni Rupa Dua Dimensi di Kelas XII MIPA 4 SMAN 2 Pekanbaru. Jurnal Penelitian Tindakan Kelas (PTK). Vol. 5.

Purwanto. (2011). Evaluasi Hasil Belajar. Pustaka Pelajar: Yogyakarta.

Sudjana. (2005). Metode Statistika. Bandung: Tarsito.

Susetyo, B. (2010). Statistka untuk Analisis Data Penelitian. Bandung: Refika Ditama.

Usman dan Setiawati. (2001). Statistika. Bandung: Remaja Rosdakarya.

Abdurrahman, M. (2009). Pendidikan Bagi Anak Berkesulitan Belajar. Jakarta Rineka Cipta. 
Akbar, S. (2013). Instrumen Perangkat Pembelajaran. Bandung: PT Remaja Rosdakarya Offset.

Amri, S. (2013). Pengembangan \& Model Pembelajaran dalam Kurikulum 2013.Jakarta: PT. Prestasi Pustaka.

Borg, W., dan Gall, M. (2003). Educational Research; an Introduction $6^{\text {th }}$ edition.Boston: Pearson.

Dimyati dan Mudjiono. (2006). Belajar dan Pembelajaran. Jakarta: Rineka Cipta.

Grinnell, Jr, Richard M. (1988). Social Work Research and Evaluation.

Third Edition. Illionis: F.E. Peacock Publishers, Inc.

Hake, R. (1999). Analyzing Change/Gain Scores. Woodland Hills: Dept. Of Physics, Indiana University.

Hudojo, H. (1988). Mengajar Belajar Matematika. Jakarta: Departemen Pendidikan dan Kebudayaan Direktorat Jenderal Pendidikan Tinggi Proyek Pengembangan Lembaga Pendidikan.

Kemendiknas. (2013). Permendiknas Nomor 70 Tahun 2013 tentang Kerangka Dasardan Struktur Kurikulum Sekolah Menengah Kejuruan/ Madras ah Aliyah Kejuruan. BSNP. http://bsnpindonesia.org/id/bsnp/wpcontent/- uploads/2013/06/08.-PermendikbudNomor-70-ttg-Kerangka-Dasar-dan- struktur - Kurikulum-SMK-MAK-danLampiran-Versi-05-06-13-Aries- edit-hukor.pdf. [28 Januari 2014]

Kemendiknas. (2014). Permendiknas RI Nomor 104 Tahun 2014 Tentang Penilaian Hasil Belajar Oleh Pendidik Pendidikan Dasar dan Pendidikan Menengah.http://pgsd.uad.ac.id/wp-content/uploads/lampiranpermendikbud-no-104-tahun-2014.pdf (Januari 2014)

Marzuki. (2006). Evaluasi Pembelajaran. Kencana Perdana Media Group. Jakarta

NCTM. (2000). Principles and Standards for School Mathematics. Reston VA: NCTM

Nurhadi, dkk. (2003). Pembelajaran Kontekstual dan Penerapannya dalam KBK. Malang: Universitas Negeri Malang

Polya, G. (1973). How To Slove It: A New Aspect of Mathematics Method. New Jersey Princeton University Press.

Rohman, M dan Amri, S. (2013). Strategi dan Desain Pengembangan Sistem Pembelajaran. Jakarta: Prestasi Pustaka.

Rusman. (2011). Model-model Pembelajaran-Mengembangkan Profesionalisme Guru. Bandung: Rajawali Pers. 
Sagala, S. (2012).Konsep dan Makna Pembelajaran. Bandung: Alfabeta Sanjaya, W. (2011). Strategi Pembelajaran Berorientasi Standar Proses Pendidikan. Penerbit Kencana Media Group: Jakarta.

Sheffield, L. J. dan Cruikshank, D. E. (1996). Teaching and Learning; Elementary and Middle School. New Jersey: Prentice Hall, Inc.

Sugiono. (2009). Metode Penelitian Pendidikan - Pendekatan Kuantitatif, Kualitatif, dan R\&D. Bandung: Alfabeta

Thiagarajan, S., Semmel, D.S. \& Semmel,M.I. (1974). Instructional Development For Training Teachers of Exceptional Children. Indiana:Indiana University Bloomington.

Tim MKPBM. (2001). Strategi Pembelajaran Matematika Kontemporer.Bandung: JICA, Universitas Pendidikan Indonesia (UPI).

Trianto (2010), Mendesain Model Pembelajaran Inovatif-Progresif.Penerbit Kencana Prenada Media Group, Jakarta. 